\title{
I mproving Secondary School Students' Achievement and Retention in Biology Through Video-based Multimedia Instruction
}

\author{
Amosa I siaka Gambari, PhD \\ Senior Lecturer in Educational Technology \\ Federal University of Technology \\ Minna, Nigeria \\ Akawo Angwal Yaki, MEd \\ Lecturer II in Science Education \\ Federal University of Technology \\ Minna, Nigeria \\ Eli S. Gana, PhD \\ Senior Lecturer in Science Education \\ Federal University of Technology \\ Minna, Nigeria \\ Queen Eguono Ughovwa, MEd \\ Senior Biology Teacher \\ Government Senior Secondary School Gwagwalada \\ Abuja, Nigeria
}

The study examined the effects of video-based multimedia instruction on secondary school students' achievement and retention in biology. In Nigeria, 120 students (60 boys and 60 girls) were randomly selected from four secondary schools assigned either into one of three experimental groups: Animation + Narration; Animation + On-screen Text; Animation + Narration + On-screen Text or a control group. The pretest, posttest experimental, and control group design was adopted. A 50-item multiple-choice objective test termed Biology Achievement Test (BAT) was used for collecting data. The validated BAT was tested for reliability using Kuder Richardson (KR20), which yielded 0.89. T-test, analysis of covariance (ANCOVA), and Scheffe's post-hoc analysis were used in determining the significant differences among the four groups. The results showed that there was no statistically significant difference among the experimental groups. Generally, students under multimedia instruction performed better than their colleagues in the conventional teaching method. However, students in conventional teaching method had better retention than other groups.

Biology is a natural science that deals with the living world: How the world is structured, how it functions and what these functions are, how it develops, how living things came into existence, and how they react to one another and with their environment (Umar, 2011). It is a prerequisite subject for many fields of learning that contributes immensely to the technological growth of the nation (Ahmed, 2008). This includes medicines, pharmacy, nursing, agriculture, forestry, biotechnology, nanotechnology, and many other areas (Ahmed \& Abimbola, 2011).

Biology is seen as one of the core subjects in Nigerian secondary school curriculum. Because of its importance, more students enrolled for biology in the senior secondary school certificate examination (SSCE) than for physics and chemistry (West African Examination Council, 2011). Biology is introduced to students at senior secondary school level as a preparatory ground for human development, where career abilities are groomed, and potentials and talents discovered and energized (Federal Republic of Nigeria, 2009). The quality and quantity of science education received by secondary school students are geared toward developing future scientists, technologists, engineers, and related professionals (Kareem, 2003). 
In spite of the importance and popularity of biology among Nigerian students, performance at senior secondary school level has been poor (Ahmed, 2008). The implication of this failure in education is that Nigeria may have shortages of manpower in science- and technology-related disciplines. This may affect Nigeria's vision to become one of the 20 industrialized nations in the world by year 2020.

Poor teaching methods adopted by teachers at senior secondary school level in Nigeria have been identified as one of the major factors contributing to poor performance of students in biology (Ahmed \& Abimbola, 2011; Kareem, 2003; Umar, 2011). The conventional teaching method is classroom-based and consists of lectures and direct instructions conducted by the teacher. This teacher-centered method emphasizes learning through the teacher's guidance at all times. Students are expected to listen to lectures and learn from them. The teacher often talks at the students instead of encouraging them to interact, ask questions, or make them understand the lesson thoroughly. Most classes involve rote learning, where students depend on memorization without having a complete understanding of the subject. Just passing the tests, consisting of descriptions, matching, and other forms of indicators, is all that matters to complete the curriculum (Adegoke, 2011; Umar, 2011).

The persistent use of this method makes students passive rather than active learners. It does not promote insightful learning and long-term retention of some abstract concepts in biology (Ahmed, 2008; Ahmed \& Abimbola, 2011; Kareem, 2003; Umar, 2011).

The picture today is that biology education is failing. The results of the Senior Secondary School Certificate Examination (SSSCE) of biology students in Nigeria as shown in Figure 1 are highly disturbing, considering the fact that the students would become future scientists.

Figure 1. Performance of Biology Students in May/ J une WASSCE, 20072011 in Nigeria at Credit Level

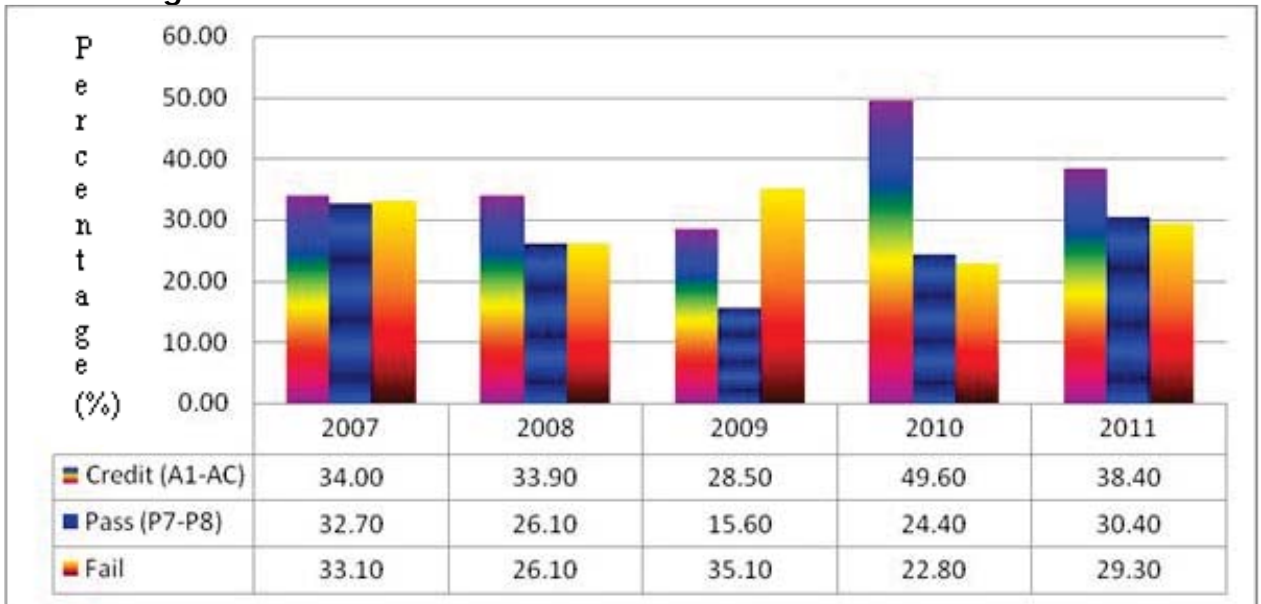

Source: West African Examination Council 2007 - 2011 Annual Report.

Figure 1 shows the percentage of students that passed biology at the Senior School Certificate Examination (SSCE) conducted by the West African Examination Council (WAEC). As the table indicates, the number of students that passed biology at credit level (A1-C6) was consistently less than $50 \%$ for the past five years (2007-2011) in Nigeria (West African Examination Council, 2011).

From research evidence, educators see the pressing need to reconsider the techniques and methods of instruction at senior secondary school level. To address these challenges, there is need for an instructional system that is supported by 
technology for meaningful learning. In this 21st century, a motivating and captivating approach should be encouraged to help students better learn, understand, and retain biology concepts and promote their future involvement. One of the promising approaches, according to Adegoke (2010); Kuti (2006); Mayer, Dow, and Mayer (2003); and Moreno and Mayer (2000), involves multimedia presentations supported in visual and verbal formats supplemented with pictures, animations, texts, and narration.

In defining multimedia learning, it is useful to distinguish among media, mode, and modality. Media refers to the system used to present instruction, such as a book-based medium, video-based medium or a computer-based medium. Mode refers to the format used to represent the lesson, such as words versus pictures. Modality refers to the information processing channel used by the learner to process the information, such as auditory versus visual (Mayer, 2005). This

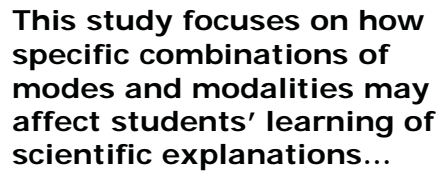

study focuses on how specific combinations of modes and modalities may affect students' learning of scientific explanations; for example, how visual-verbal material (i.e., text) or auditory-verbal material (i.e., narration) is combined with visual-nonverbal materials (i.e., graphics, video or animations). Students' interest and retention could be aroused and retained through the use of multimedia instructional approach (Adegoke, 2010). Starbek, Eriavec, and Peklai (2010) reported that students acquired better knowledge retention and improved comprehension skills more than the other groups when taught genetics with multimedia. Similarly, Achebe (2008) and Gambari and Zubairu (2008) found that students who were taught food and nutrition at senior secondary school level, and pupils taught primary science at nursery and primary school levels, performed better and had better retention than those taught with traditional methods respectively.

According to Kim and Gilman (2008), it is necessary to apply learning theories in designing effective multimedia instruction. For instance, Mayer and his colleagues propounded six principles of multimedia learning: (a) the multimedia principle - students learn better from words and pictures than from words alone; (b) the spatial contiguity principle - students learn better when corresponding words and pictures are presented close or next to each other rather than far apart on the page or screen; (c) the temporal contiguity principle - students learn better when corresponding words and pictures are presented simultaneously rather than successively; (d) the coherence principle - students learn better when extraneous words, pictures, and sounds are excluded rather than included; (e) the modality principle - students learn better when words in a multimedia are presented as spoken rather than printed text; (f) the redundancy principle - students learn better from animation and narration than from animation, narration, and on-screen text (Mayer, 2001).

According to Adegoke (2011), all six principles have been proven repeatedly in empirical research e.g., Mayer, Bove, Bryman, Mars, and Tapangco (1996) for multimedia principle; Mousavi, Low and Sweller (1995) for modality principle; Mayer, Heiser, and Lonns (2001); Moreno \& Mayer (2000); Tabbers, Martens, and Van-Merriëboer (2004) for redundancy principle. However, Thalheimer (2004) has reported findings that were not in consonance with Mayer's (2001) multimedia learning principle. For instance, Muller, Lee, and Sharma (2008) found that the redundancy principle did not transfer to normal classroom situations. In their study, Muller et al. (2008) suggested that addition of interesting information may help maintain the learners' interest in a normal classroom environment.

The effective use of animation and its positive results on instructional message design is made evident by other research. For instance, Nusir, Alsmadi, Al-Kabi, and Shardqah (2010) found that the computer animation learning courseware had positive effects on students' academic performance and achievement level (high and low). 
Moreno and Mayer (2000) and Tabbers et al. (2004) found that learning outcomes of students who learnt physics with courseware version of animation + narration were better than their colleagues who learnt physics either with animation + on-screen text or animation + narration + on-screen text. Mayer and Anderson (1991) reported that simultaneous presentation of animation and narration improved learning. However, Grobe and Struges cited in Saibu (2002) found that those taught through the conventional teaching methods achieved a mean posttest score slightly higher than those taught by the audio-tutorial (narration) method.

Studies on animation + narration + on-screen text were made evident by Mubaraq's (2009) results that a still picture is better than (sound) words, animation better than a still picture, and sound better than silence. This was supported by Adegoke (2010), Adegoke (2011), and Chuang (1999) in their studies which examined the effect of

...it is well recognized that multimedia remains the key towards improving learning outcomes. animation, narration, and on screen text-based materials when combined simultaneously; the result showed that students in the animation + narration + onscreen text group scored significantly higher on the postphysics achievement test than their colleagues who were in the animation + narration only group, as well as those who were in the animation + on-screen text group. These studies were also not in agreement with the redundancy principle. However, Okwo and Asadu (2002) reported that three media (video, audio + picture, and audio) were found to be equally effective with no significant difference effect among the means when used for teaching physics.

From the foregoing, it is well recognized that multimedia remains the key towards improving learning outcomes. However, the extent to which this has been achieved has not yet been addressed in biology education. Therefore, this study investigates improving secondary school students' achievement and retention in biology through video-based multimedia instruction.

\section{Purpose of the Study}

The main purpose of this study was to investigate whether video-based multimedia instruction could improve secondary school students' achievement and retention in biology.

Specifically, the study examined the effects of:

(i) animation + narration, animation + on-screen text, and animation + narration + on-screen text packages and those exposed to conventional teaching method as posttest.

(ii) animation + narration, animation + on-screen text, and animation + narration + on-screen text packages and those exposed to conventional teaching method as delayed posttest.

\section{Research Questions}

(i) What are the differences in the mean achievement scores of senior secondary school biology students exposed to animation + narration, animation + on-screen text, and animation + on-screen text + narration instructional packages?

(ii) What are the differences in the mean retention scores of senior secondary school biology students exposed to the VBMI instructional packages?

\section{Research Hypotheses}

The following hypotheses were formulated and tested at 0.05 level:

$\mathbf{H}_{\mathbf{1}}$ : There is no significant difference in the mean achievement scores of senior secondary school biology students exposed to VBM instructional packages, and those exposed to conventional teaching method. 
$\mathbf{H}_{\mathbf{2}}$ : There is no significant difference in the mean retention scores of senior secondary school biology students exposed to the same instructional packages and those exposed to conventional teaching method.

\section{Methodology}

The research design adopted for the study was a pretest, posttest experimental control group design. The study involved four levels of independent primary variable (three treatments and a control) on students' achievement in Biology. The design layout is as shown in Table 1.

Table 1

Research Design Layout

\begin{tabular}{lllll}
\hline Groups & Pretest & Treatment & Posttest & Retention Test \\
\hline Experimental Group I & $\mathrm{O}_{1}$ & $\mathrm{~A}+\mathrm{N}$ & $\mathrm{O}_{2}$ & $\mathrm{O}_{3}$ \\
Experimental Group II & $\mathrm{O}_{4}$ & $\mathrm{~A}+\mathrm{T}$ & $\mathrm{O}_{5}$ & $\mathrm{O}_{6}$ \\
Experimental Group III & $\mathrm{O}_{7}$ & $\mathrm{~A}+\mathrm{N}+\mathrm{T}$ & $\mathrm{O}_{8}$ & $\mathrm{O}_{9}$ \\
Control Group & $\mathrm{O}_{10}$ & $\mathrm{X}_{0}$ & $\mathrm{O}_{11}$ & $\mathrm{O}_{12}$ \\
\hline
\end{tabular}

Key:

Where:

$\mathrm{A}+\mathrm{N}=$ Animation + Narration

$\mathrm{A}+\mathrm{T}=$ Animation + On-screen Text

$\mathrm{A}+\mathrm{N}+\mathrm{T}=$ Animation + Narration + On-screen Text

Xo $=$ No Treatment (Conventional Teaching Method)

The population of the study comprised all senior secondary class two (SSII) students. The students' population consisted of 2010/2011 set obtained from Abuja Education Board. The choice of SS II students ensured that students used for the study were already familiar with the course and not preparing for any external examination.

A multistage sampling technique was used for the allocation of schools for the study. At first stage, purposive sampling technique was used to select four coeducational secondary schools from Gwagwalada Area Council, Abuja, Nigeria, that have computers, Liquid Crystal Display (LCD) projectors, and other facilities. Second, the schools were randomly assigned to experimental groups and control group (conventional teaching method) through hat draw method. Thirdly, simple sampling technique was used to select the 120 SSII biology students. There were four groups and each group had 30 students.

Biology Achievement Test (BAT) was used in collecting data for the study. The BAT consists of 50 multiple choice objective items with five options (A - E) adapted from past examinations of West African Examination Council (West African Examination Council, May/June, 1988-2011) and National Examination Council (NECO, June/July, 1988-2011). BAT was validated by experts in biology education and test and measurement, and its reliability coefficient determined as 0.79 using Kuder Richardson (KR20). The same instrument was re-used for the retention test after four weeks.

Video-Based Multimedia Instructional (VBMI) packages were developed and used as a treatment instrument for the study. The packages consist of concepts of fungi in biology. The necessity for researcher-made VBMI packages was based on 
the fact that the commercially produced instructional packages are not directly relevant to the topic or objectives to be achieved in this study. Thus, developing a VBMI package for this study was inevitable.

The VBMI packages were validated by biology experts and educational technology specialists. Four senior lecturers from Biology Education Department, Federal University of Technology, Minna, Nigeria; four senior lecturers from Educational Technology, University of Ilorin, Nigeria; four biology teachers from senior secondary schools in Minna; and four subject experts in the Test and Measurement Department, National Examination Council (NECO), Nigeria, all validated the content of biology, and the appropriateness and structure of VBMI packages. The three packages were field tested on some selected students within the population but outside the sampled schools. The comments and observations from valuators and students were used to modify the packages. The biology content for experimental groups was produced on a CD-ROM and installed in the system, while the control group used the same content, but was not exposed to VBMI packages.

Experimental procedure for data collection included various stages. The researchers visited the selected schools and sought the cooperation of their students and staff. The biology teachers were then trained as research assistants in the use of the video-based multimedia instructional (VBMI) packages. Biology Achievement Test (BAT) was administered to sample students as pretest to ascertain the academic equivalence of the students before the treatments. The treatment was administered for four weeks. The VBMI packages were projected onto the screen via LCD projector. Students read, listened, and watched the video of the lesson based on the mode of multimedia instructional approaches to different groups. After class presentation, students had opportunities of interacting with the animation by clicking on Next, Previous, Pause, and Stop buttons at their convenience using standalone computer.

Experimental Group I: Animation + Narration only: Thirty students in this group watched the video which showed animations depicting the explanations of the fungi concepts along with concurrent narration by a female voice.

Experimental Group II: Animation + On-Screen text only: The students in this group watched the video which showed animations depicting concepts of yeast, fungi, and production of bread, with concurrent presentation of on-screen text. To reduce cognitive load, the corresponding words and picture were presented next to each other on the page.

Experimental Group III: Animation + On-Screen Text + Narration: Thirty students were in this group. The students watched the video, which showed animations depicting the explanations of concepts of yeast, fungi, and production of bread via narration by a female voice along with concurrent on-screen text.

Control Group: Conventional Teaching Method: The control group was exposed to lecture method. The subject teacher presented the lesson using charts, drawings, and pictures to explain the concept of yeast, fungi, and production of bread. The students listened and wrote down some key points during presentation.

Immediately after four weeks of treatment, BAT was administered as posttest to measure the achievement of different groups. Four weeks after the posttest, BAT was reshuffled and administered as a retention test. The scores obtained were subjected to data analysis based on the formulated hypotheses. Analysis of covariance (ANCOVA) and Scheffe's post-hoc analysis was employed. The significance of the various statistical analyses was ascertained at 0.05 alpha level. The research design adopted for the study was a pretest, posttest experimental control group design. The study involved four levels of independent primary variable (three treatments and a control) on students' achievement in Biology. The design layout is as shown in Table 1.

\section{Results}

The results are presented based on the research hypotheses: 
Hypothesis One: There is no significant difference in the mean achievement scores of senior secondary school biology students exposed to animation + narration, animation + on-screen text, and animation + on-screen text + narration instructional packages, and those exposed to conventional teaching method. To determine whether there was significant difference in the posttest mean scores of the students in experimental groups with VBM instructional packages and those in control group (conventional teaching method), data were analyzed using the analysis of covariance (ANCOVA). Table 2 contains the result of the analysis.

Table 2

ANCOVA Posttest on Experimental Groups I, II, III and Control (CTM) Group

\begin{tabular}{llllll}
\hline $\begin{array}{l}\text { Source of } \\
\text { Variation }\end{array}$ & $\begin{array}{l}\text { Sum of } \\
\text { Square }\end{array}$ & df & Mean Square & $F$ & \multicolumn{2}{c}{$\begin{array}{l}\text { Significance } \\
\text { of F }\end{array}$} \\
\hline $\begin{array}{l}\text { Covariate } \\
\text { (Pre-test) }\end{array}$ & 114.767 & 1 & 114.767 & 1.930 & 0.167 \\
$\begin{array}{l}\text { Main Effect } \\
\text { (Treatment) }\end{array}$ & 19672.072 & 3 & 6557.357 & 110.299 & 0.000 \\
$\begin{array}{l}\text { Model } \\
\text { Residual }\end{array}$ & 19672.467 & 4 & 4918.117 & 82.726 & 0.000 \\
Total & 6836.833 & 115 & 59.451 & & \\
\hline
\end{tabular}

Table 2 shows that an $F(1,115)=110.299, p=0.000$ for the main effect (treatment) was significant. This indicates that the method of instruction produced a significant effect on the posttest mean scores of students when covariate effect (pretest) was controlled. The result indicates that there was significant difference between the students exposed to VBMI (animation + narration; animation + onscreen text; and animation + on-screen text + narration instructional packages) and those exposed to conventional teaching method (CTM). Hence, $\mathrm{H}_{1}$ was rejected. Therefore, there is significant difference among students taught biology with VBMI packages and conventional teaching method. Scheffe's post-hoc analysis was further carried out to determine the area of differences in Table 3.

Table 3

Scheffe's Post-hoc Analysis of the Groups Mean Scores

\begin{tabular}{lllllll}
\hline Groups & $\begin{array}{l}\text { Mean } \\
\text { Scores }\end{array}$ & $\begin{array}{l}\text { Group } \\
(\mathrm{A}+\mathrm{N})\end{array}$ & $\begin{array}{l}\text { Group } \\
(\mathrm{A}+\mathrm{T})\end{array}$ & $\begin{array}{l}\text { Group III } \\
(\mathrm{A}+\mathrm{N}+\mathrm{T})\end{array}$ & $\begin{array}{l}\text { Group } \\
(\mathrm{CTM})\end{array}$ \\
\hline Group I & 73.33 & & 0.130 & 0,981 & $* 0.000$ & IV \\
Group II & 69.40 & 0.130 & & 0.110 & $* 0.000$ \\
Group III & 73.73 & 0.981 & 0.110 & & $* 0.000$ \\
Group IV & 42.93 & $* 0.000$ & $* 0.000$ & $* 0.000$ & \\
\hline
\end{tabular}

* The mean difference is significant at the 0.05 level.

The results in Table 3 indicate that there was significant difference in the posttest mean scores of students exposed to $A+N(X=73.33)$ and CTM $(X=42.93)$ in favour of experimental group I $(A+N)$, that is, those exposed to Animation + Narration. The results also indicate that significant difference exists in the posttest scores of students exposed to $A+T(X=69.40)$ and CTM (42.93) in favour of experiment group II. In addition, the results show that students were exposed to 
$\mathrm{A}+\mathrm{N}+\mathrm{T}(\mathrm{X}=73.73)$ and CTM (42.93) in favour of experimental group III. This implies that experimental groups outperformed the control group.

The performances of students in the four groups were further compared based on the mean gain scores between the pretest and posttest for each group, and the results are shown in Table 4 graphically illustrated in Figure 2.

Table 4

Mean Gain Scores for Treatment and Control Groups

\begin{tabular}{lccl}
\hline Groups & Pretest & Posttest & $\begin{array}{l}\text { Mean Gain } \\
\text { Score }\end{array}$ \\
\hline Animation + Narration (A + N) & 42.57 & 73.33 & 30.76 \\
Animation + Text (A + T) & 40.53 & 69.40 & 28.87 \\
Animation + Narration + Text (A + N + 42.30 & 73.73 & 31.43 \\
T) & & & \\
Conventional Teaching Method (L) & 40.77 & 42.93 & 2.16 \\
\hline
\end{tabular}

From Table 4 it was observed that all the groups had improved performance in posttesting. For instance, animation + narration + on-screen text had the highest mean gain score of 31.43, followed by animation + narration with the mean gain score of 30.76; then, animation + text with the mean gain score of 28.87, while the conventional teaching method had the least mean gain score of 2.16. This implies that all the groups benefited from the treatment, with animation + narration + on-screen text having the best achievement, as illustrated in Figure 2.

Figure 2. Graphical I llustration of Students' Posttest Achievement in Biology Using Animation + Narration, Animation + Text, Animation + Narration + Text and Conventional Teaching Method

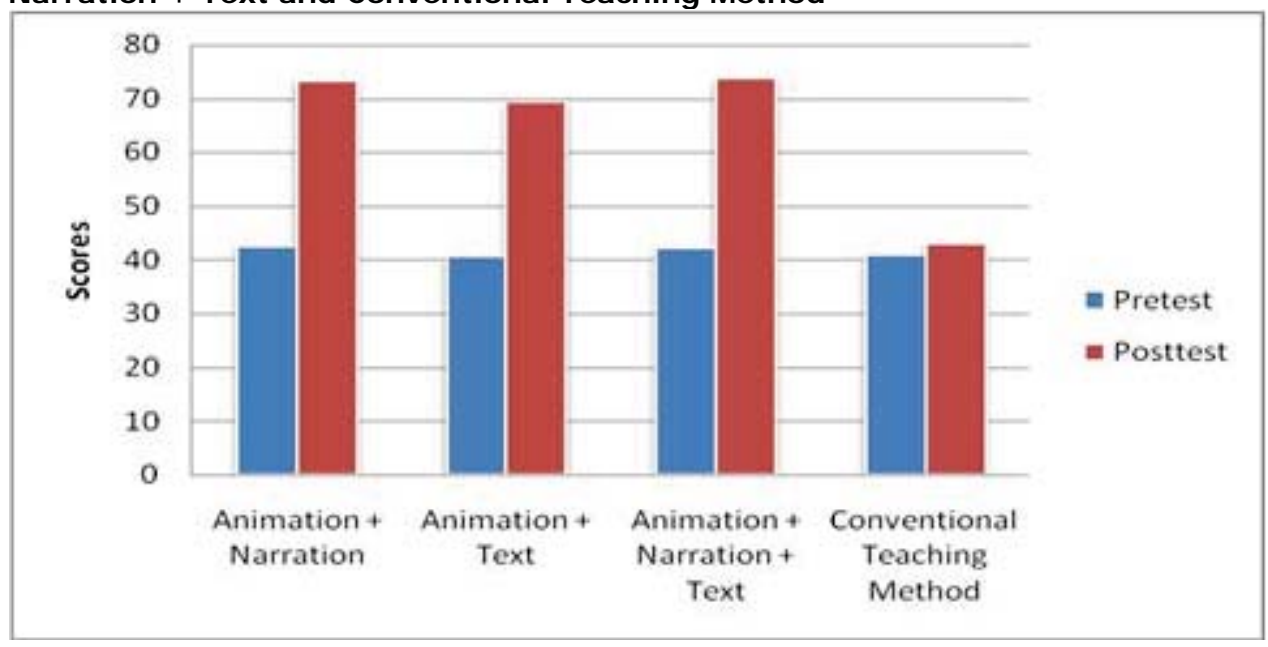

Hypothesis Two: There is no significant difference in the mean retention scores of senior secondary school biology students exposed to VBMI packages, and those exposed to conventional teaching method.

To determine whether there were significant differences in the retention mean scores of groups with the VBMI packages, and those exposed to conventional teaching method, data were analyzed using the analysis of covariance (ANCOVA), as shown in Table 5. 
Table 5

ANCOVA Posttest on Experimental Groups I, II, III and Control (CTM) Group

\begin{tabular}{llllll}
\hline $\begin{array}{l}\text { Source of } \\
\text { Variation }\end{array}$ & $\begin{array}{l}\text { Sum of } \\
\text { Square }\end{array}$ & df & Mean Square & F & \multicolumn{2}{c}{$\begin{array}{l}\text { Significance } \\
\text { of F }\end{array}$} \\
\hline $\begin{array}{l}\text { Covariate } \\
\text { (Pretest) }\end{array}$ & 142.121 & 1 & 142.121 & 2.384 & 0.125 \\
$\begin{array}{l}\text { Main Effect } \\
\text { (Treatment) }\end{array}$ & 3629.919 & 3 & 1209.973 & 20.292 & 0.000 \\
Model & 3697.721 & 4 & 924.430 & 15.504 & 0.000 \\
Residual & 6857.079 & 115 & 59.627 & & \\
Total & 323900.000 & 120 & & & \\
\hline
\end{tabular}

Table 5 shows that an $F(1,115)=20.292, p=0.000$ for the main effect (treatment) was significant. This indicates that the method of instruction produced a significant effect on the retention mean scores of students when covariate effect (pretest) was controlled. The result indicates that there was significant difference among the students exp osed to VBMI (animation + narration; animation + onscreen text; and animation + on-screen text + narration instructional packages) and those exposed to conventional teaching method (CTM). Hence, $\mathrm{H}_{2}$ was rejected. Therefore, there is significant difference in the retention test among students taught biology with VBMI packages and conventional teaching method. Scheffe's post-hoc analysis was further carried out to determine the area of differences in Table 6.

In order to establish the direction of significant differences among the four groups, Scheffe's post-hoc analysis was employed as shown in Table 7.

Table 6

Scheffe's Post-hoc Analyses of the Groups' Mean Scores

\begin{tabular}{lllllll}
\hline Groups & $\begin{array}{l}\text { Mean } \\
\text { Scores }\end{array}$ & $\begin{array}{l}\text { Group } \\
(\mathrm{A}+\mathrm{N})\end{array}$ & $\begin{array}{l}\text { Group } \\
(\mathrm{A}+\mathrm{T})\end{array}$ & $\begin{array}{l}\text { Group III } \\
(\mathrm{A}+\mathrm{N}+\mathrm{T})\end{array}$ & $\begin{array}{l}\text { Group } \\
(\mathrm{CTM})\end{array}$ \\
\hline Group I & 51.27 & & 0.888 & $* 0.020$ & $* 0.000$ \\
Group II & 52.87 & 0,888 & & 0.132 & $* 0.000$ \\
Group III & 57.67 & $* 0.020$ & 0.132 & & $* 0.001$ \\
Group IV & 42.60 & $* 0.001$ & $* 0.000$ & $* 0.000$ & \\
\hline
\end{tabular}

$*$ The mean difference is significant at the 0.05 level.

The results in Table 6 indicates that there was significant difference in the retention mean scores of students exposed to $A+N(X=51.27), A+N+T(57.67)$ and $\mathrm{CM}(\mathrm{X}=42.60)$ in favour of experimental group III $(A+N+T)$ followed by experimental group II $(A+T)$. Table 6 also indicates that significant difference exists in the retention scores of students exposed to $A+T(X=52.87)$ and CTM (42.60) in favour of experiment group II. In addition, the results show significant difference between students exposed to $A+N+T(X=57.67), A+N(51.27)$ and CTM (42.60) in favour of experimental group III, followed by experimental group I. However, no significant difference exists between experimental groups II and III. 
The achievements of students in the four groups were further compared based on the mean gain score between the posttest and retention test for each group. The results are shown in Table 7 and graphically illustrated in Figure 3.

Table 7

Mean Gain Scores for Treatment and Control Groups

\begin{tabular}{llll}
\hline Groups & Posttest & $\begin{array}{l}\text { Retention } \\
\text { Test }\end{array}$ & $\begin{array}{l}\text { Mean Gain } \\
\text { Score }\end{array}$ \\
\hline Animation + Narration (A+N) & 73.33 & 51.27 & 22.06 \\
Animation + Text (A + T) & 69.40 & 52.87 & 16.53 \\
Animation + Narration + Text (A + N + T) & 73.73 & 57.67 & 16.06 \\
Conventional Teaching Method (L) & 42.93 & 42.60 & 0.33 \\
\hline
\end{tabular}

Table 7 showed that the groups' achievement dropped after four weeks of treatment. For instance, the mean gain score of 22.06 was obtained by groups in animation + narration; 16.53 by animation + text; animation + narration + text had 16.06, while the conventional teaching method had mean gain difference of 0.33 . This implies that conventional teaching method retained more than Animation + Narration, followed by Animation + Text, then by Animation + Narration.

\section{Figure 3. Graphical I llustration of Students' Retention Achievement in Biology Using Animation + Narration, Animation + Text, Animation + Narration + Text and Conventional Teaching Method}

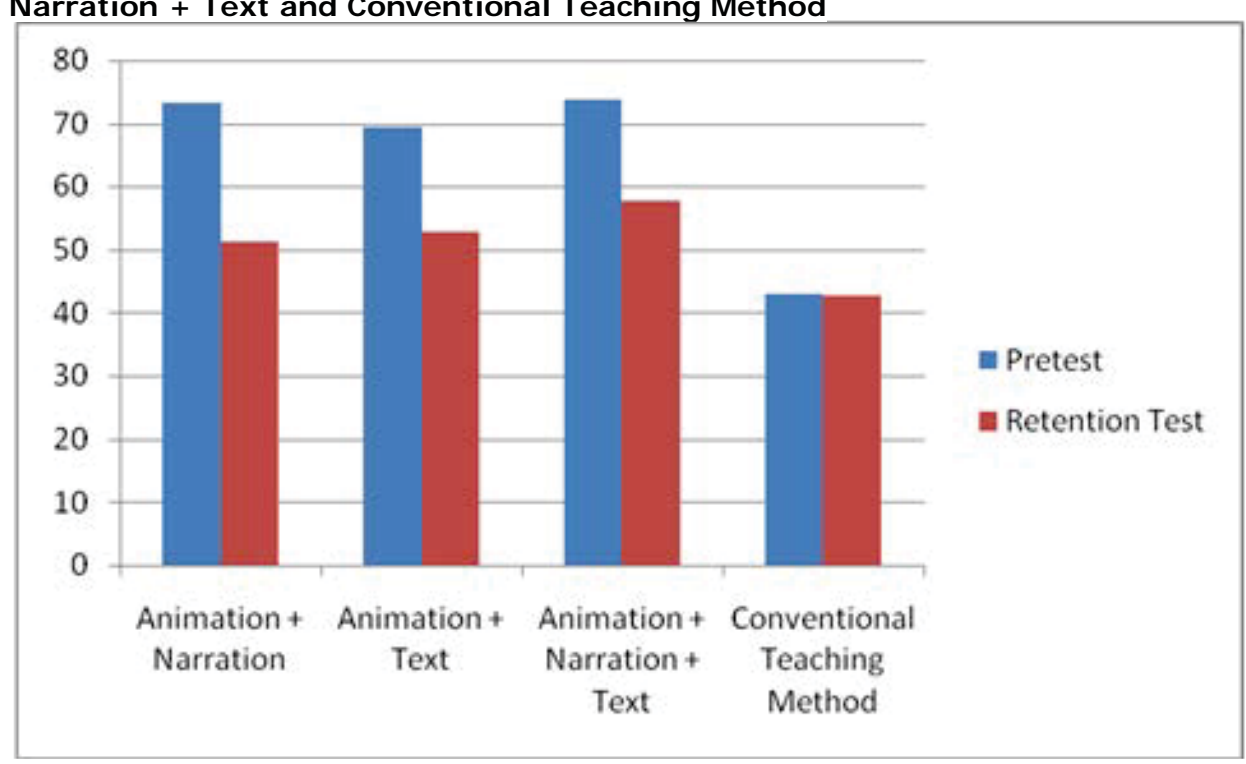

Discussion

$\mathbf{H}_{\mathbf{1}}$ : There is no significant difference in the mean achievement scores of senior secondary school biology students exposed to animation + narration, animation + on-screen text, and animation + on-screen text + narration instructional packages and those exposed to conventional teaching method. 
The results of Hypothesis One revealed that there was in fact significant difference among students' achievements in favour of the experimental groups against control group. The results indicated that students exposed to animation + narration outperformed those exposed to conventional teaching method; similarly, those exposed to animation + text performed better than those exposed to conventional teaching method; finally, those exposed to animation + narration + on-screen text performed better than those taught with conventional teaching method.

...students exposed to animation + narration outperformed those exposed to conventional teaching method...

The results concurred with the findings of Okwo and Asadu (2002), who reported that three media (video, audio + picture, and audio) were found to be equally effective with no significant difference effect among the means when used for teaching physics. This also agrees with Sawsan et al. (2011) who found that the computer animation learning courseware had positive effects on students' academic performance and achievement level (high and low) and their learning styles.

However, the findings contradicts those of Grobe and Struges cited in Saibu (2002), who found that those students taught through the conventional teaching method achieved a mean posttest score slightly higher than those taught by the audio-tutorial (narration) method.

\section{Teachers should expose biology students to video- based multimedia instructional strategies so as to promote effective and active learning...}

The results of this experiment failed to validate Mayer's (2001) multimedia redundancy principle. They also disagree with the findings of Chuang (1999), Adegoke (2010), and Adegoke (2011), who found that students in the animation + on-screen text + narration performed better than those in animation + on-screen text, animation + narration and lecture method. These findings are not in consonance with the findings of Moreno and Mayer (2000) and Tabbers et al. (2004), who found that learning outcomes of students who learnt physics with courseware version of animation + narration were better than their colleagues who learnt physics either with animation + on-screen text or with animation + narration + on-screen text.

$\mathbf{H}_{\mathbf{2}}$ : There is no significant difference in the mean retention scores of senior secondary school biology students exposed to VBM instructional packages and those exposed to conventional teaching method.

The results of Hypothesis Two showed that there is significant difference in retention achievement of students taught biology with video-based multimedia instructional packages. Students in animation + narration, and those in animation + narration + on-screen text groups had better retention than their colleagues in animation + on-screen text and conventional teaching method. These results agree with the findings of Gambari and Zubairu (2008) and Achebe (2008); Moreno and Mayer (2000); Tabbers et al. (2004); and Starbek et al. (2010), who found that students taught genetics with multimedia acquired better knowledge, retention, and improved comprehension skills than other groups.

\section{Conclusion}

This paper has examined the multimedia, theoretical framework for designing effective multimedia for biology at secondary school level, and relevant studies on modes of multimedia. It is the view of the authors that there is still a wide gap to be bridged in the area of teaching and learning. The innovative technology using video-based animation seems to be the answer and the bridge. The concurrent use of animation + narration + on-screen text in an instructional interface was more effective in teaching the biological concepts of fungi. However, it did not improve students' retention. 


\section{Recommendations}

Based on the major findings of this study, the following recommendations are offered. Teachers should expose biology students to video-based multimedia instructional strategies so as to promote effective and active learning, motivation, learning by doing, and learning by experience among students. Also, teacher education programmes in Nigerian tertiary institutions should be improved upon to prepare teachers who can apply innovative approaches (multimedia instructional strategies) that will promote effective teaching and learning. Also, instructional designers and instructional material developers should develop relevant video-based instructional packages for use within the Nigerian school systems.

In addition, this study established that conventional teaching method improved students' retention better than video-based multimedia packages. Therefore, future research should be conducted focusing on the technologyenhanced instructional settings rather than on conventional teaching method on the retention of students in learning processes should be conducted.

\section{References}

Achebe, A. E. (2008). Effect of videotape instructional package on achievement and retention in food and nutrition at senior secondary school level in Minna, Niger State. JOSTMED, 1(1), 33-39.

Adegoke, B. A. (2010). Integrating animations, narrations and textual materials for improving students' learning outcomes in senior secondary school physics. Electronic J ournal of Research in Educational Psychology, 8(2), 725-748.

Adegoke, B. A. (2011). Effect of multimedia instruction on senior secondary school students' achievement in Physics. European Journal of Educational Studies, 3(3), 537-541.

Ahmed, M. A. (2008). Influence of personality factors on biology lecturers' assessment of difficulty levels of genetics concepts in Nigerian colleges of education (Unpublished doctoral thesis). University of Ilorin, Ilorin, Nigeria.

Ahmed, M. A., \& Abimbola, I. O. (2011). Influence of teaching experience and school location on biology teachers' rating of the difficult levels of nutrition concepts in Ilorin, Nigeria. JOSTMED, 7(2), 5261.
Chuang, Y. (1999). Teaching in a multimedia computer Environment: A study of the effects of learning style, gender and math achievement. Interactive Multimedia Electronic Journal of Computer - Enhanced Learning, 1(1).

Federal Republic of Nigeria. (2009). National policy on education. Abuja: NERDC Press.

Gambari, A. I., \& Zubairu, A. A. (2008). I mpact of videotape instructional package on achievement and retention in primary science among primary pupils in Niger State, Nigeria. Paper presented at the meeting of the $2^{\text {nd }}$ SSSE Annual National Conference, Federal University of Technology, Minna, Nigeria.

Kareem, L. O. (2003). Effects of audio-graphic self-instructional packages on senior secondary school students' performance in biology in Ilorin, Nigeria. Unpublished PhD thesis of the University of Ilorin, Ilorin.

Kim, D., \& Gilman, D. A. (2008).

Effects of text, audio, and graphic aids in multimedia instruction for vocabulary learning. Educational Technology \& Society, 11(3), 114126. 
Mubaraq, D. K. (2009). The effects of using different types of multimedia presentations on learners' understanding of physics concept (Unpublished doctoral thesis). Northern Illinois University, DeKalb, IL.

Kuti, J. B. (2006). Effect of multimedia instructional strategy on Senior Secondary Students' learning outcomes in Physics in Ogun State, Nigeria (Unpublished master's project). University of I badan, I badan, Nigeria.

Mayer, R. E. (2001). Multimedia learning. Cambridge, UK: Cambridge Press University.

Mayer, R. E. (2005). Cognitive theory of multimedia learning. In R.E. Mayer (Ed.), The Cambridge Handbook of Multimedia Learning (pp. 31-48). New York, NY: University of Cambridge.

Mayer, R. E., \& Anderson, R. B. (1991). Animations need narrations: An experimental test of a dual-coding hypothesis. Journal of Educational Psychology, 83, 484-490.

Mayer, R. E., Bove, W., Bryman, A., Mars, R., \& Tapangco, L. (1996). When less is more: Meaningful learning from visual and verbal summaries of science textbook lessons. Journal of Educational Psychology, 95, 806-813.

Mayer, R. E., Dow, G. T., \& Mayer, S. (2003). Multimedia Learning in an interactive self-explaining environment: What works in the design of agent-based micro worlds? Journal of Educational Psychology, 95, 806-813.

Mayer, R. E., Heiser, J., \& Lonns, S. (2001). Cognitive Constraints on Multimedia learning: When presenting more material results in less understanding. Journal of Educational Psychology, 93, 187-198.
Moreno, R., \& Mayer, R. E. (2000). A coherence effect in multimedia learning. The case of minimizing irrelevant sounds in the design of multimedia instructional messages. Journal of Educational Psychology, 97, 117-125.

Mousavi, S. Y., Low, R., \& Sweller, J. (1995). Reducing cognitive load by mixing auditory and visual presentation modes. Journal of Educational Psychology, 87, 319-334.

Muller, D. A., Lee, K. J., \& Sharma, M. D. (2008). Coherence or interest: Which is most important in online multimedia learning? Australasian Journal of Educational Technology, 24, 211-221.

Nusir, S., Alsmadi, I., Al-Kabi, M., \& Shardqah, F. (2010, April). Designing an interactive multimedia learning system for the children of primary schools in Jordan. Paper presented at the meeting of the IEEE Global Engineering Education Conference, Amman, Jordan.

Okwo, F. A., \& Asadu, C. O. (2002). Comparative effect of three modes of mediated instruction on secondary school students achievement in physics. International J ournal of Arts and Technology Education, 2(1), 137-144.

Saibu, A. (2002). Effects of replay and ability on students' skill acquisition in slabbing when exposed to video demonstration (Unpublished master's thesis). University of Nigeria, Nsukka, Nigeria.

Starbek, P., Eriavec, M. S., \& Peklai, C. (2010). Teaching genetics with multimedia results in better acquisition of knowledge and improvement in comprehension. Journal of Computer Assisted Learning, 26(3), 214-224.

Tabbers, K. H., Martens, L. R., \& VanMerriëboer, J. J. (2004). Multimedia instructions and cognitive load theory: Effects of modality and cueing. British J ournal of Educational Psychology, 74(1), 71-82. 
Thalheimer, W. (2004). Bells, whistles, neon, and purple prose: When interesting words, sounds and visuals hurt learning and performance - a review of the seductive-augmentation research. Retrieved from http://www.worklearing.com/seductive_augmentation. htm
Umar, A. A. (2011). Effects of biology practical activities on students' process skill acquisition in Minna, Niger State, Nigeria. JOSTMED, 7(2), 118-126.

West African Examination Council. (2011). Chief Examiners' reports. Lagos: WAEC.

Amosa Isiaka Gambari, PhD, is a Senior lecturer in Educational Technology Department, School of Technology Education, Federal University of Technology, Minna, Nigeria. He received his NCE (Tech. Edu), BEd, M.Tech., PhD in Educational Technology. His research interests are Information and Communication Technologies (ICTs) Application in Education, Instructional Design, Distance Education, Mobile Learning, Cooperative Learning, and Problem-Based Learning. He is presently the Coordinator, Centre for Open and Distance Learning, University of Ilorin, Nigeria. He is a member of many professional associations, and he has many international publications to his credit.

Akawo Angwal Yaki, MEd, is a Lecturer II in the Science Education Department, School of Technology Education, Federal University of Technology, Minna, Nigeria. He received his bachelor and masters' degrees in Biology Education from FUT, Minna and University of Abuja, Nigeria. He is currently pursuing his Doctoral Degree (PhD) at University of Malaya, Malaysia. His research interests are Computer-Assisted Instruction, Discovery and Inquiry Based Learning, and Virtual Laboratory.

Eli S. Gana, PhD, is a Senior Lecturer in Science Education Department, School of Technology Education, Federal University of Technology, Minna, Nigeria. He received his NCE (Mathematics Education), bachelor degree (BEd) in Mathematics Education, master's degree (MEd) in Instructional Technology and doctor of philosophy (PhD) in Educational Technology. His research interests are Educational Technology, Computer in Education, and Instructional Design. He is a member of many professional associations and has several publications to his credit.

Queen Eguono Ughovwa, MEd is a senior Biology teacher at Government Senior Secondary School Gwagwalada, Abuja, Nigeria. She has a bachelor and master's degrees in Biology Education from Science Education Department, FUT, Minna, Nigeria. Her research interests are Biology Education, Multimedia Instructional Package, Computer in Education, and Instructional Design. She is a member of Science Teachers Association of Nigeria (STAN), Teacher Registration Council of Nigeria (TRCN) and she has several publications to her credit. 